\title{
Eupithecia oxycedrata (Rambur, 1833) (Lepidoptera: Geometridae): a new species for the fauna of Hungary
}

\author{
B. TÓTH \\ Balázs Tóth, Lepidoptera Collection, Department of Zoology, Hungarian Natural History Museum \\ Baross utca 13,H-1088,Budapest, Hungary.Email: toth.balazs@nhmus.hu
}

\begin{abstract}
First records of Eupithecia oxycedrata from Hungary are presented. This species can usually be distinguished from similar species by the elongated forewing and parallel transverse lines; the row of large spines in the female genitalia provides unambiguous identification. Accidental introduction with host plant is considered to be the most probable explanation of this occurrence, far from its Mediterranean area. The hereby presented records are the northernmost occurrence of the species. With eight figures.
\end{abstract}

Keywords. Carpathian Basin, Gábor Rácz, László Diószeghy, Juniperus, Zemplén Mountains, new record.

\section{INTRODUCTION}

$\mathrm{T}$ he Hungarian Natural History Museum (HNHM) obtained several private collections of amateur lepidopterists since its foundation. One of these accessions is the collection of Gábor Rácz, of which some families e.g. Geometridae, are still not incorporated to the main collection. He collected 572 specimens of Eupithecia, mostly around Telkibánya (Zemplén Mountains, Hungary) and later at his cottage in Bakonykúti (Bakony Mountains, Hungary) but as the material testifies, he also exchanged specimens with Edmond de Laever (Liège, Belgium), who prepared various studies on the genus Eupithecia (e.g. de Laever 1960).

The genus Eupithecia Curtis, 1825 is one of the most species-rich genera in the order Lepidoptera, comprising more than 1300 species worldwide, 128 species in Europe (Mironov, 2003) and 68 species in Hungary (Pastorális et al. 2016).

The Eupithecia curatorial work of the Rácz collection is in progress, and will contribute new data to the project cataloguing all the Eupithecia specimens collected in the Carpathian Basin and housed in the HNHM. This is why it was a great surprise that among the geometrid moths of Gábor Rácz I found five specimens with unusual pattern I could not assign to any species known from Hungary. Subsequently, I was able to identify these specimens as Eupithecia oxycedrata, which is a Mediterranean species occurring from southern Portugal to the northeastern corner of Turkey mainly along seashores; its northernmost records are from Provence (France), Retezat Mountains (Romania: Diószeghy 1929-1930) and Crimea. Its primary host plant is Juniperus oxycedrus L.; a Mediterranean gymnosperm of macchia scrubland and also wet montane forest, from sea-level to $2200 \mathrm{~m}$ (Farjon 2013).

Hereby I report and discuss these data of $E u$. oxycedrata originating from Hungary.

\section{MATERIAL AND METHODS}

To facilitate identification two specimens were dissected via the conventional method i.e. macerated in $\mathrm{KOH}$, stained with eosine and mounted 
in Euparal to provide permanent microscopic slides. The moths were photographed with Olympus B 101 camera, the slides with Olympus DP70 photographic microscope. Images were processed and figures were made with the program Adobe Photoshop CS2.
Material examined. "Sátor-hg., Telkibánya, leg. Rácz Gábor": 1 o: 28.V.1963; slide No. TB1809f (Figs. 1, 6), 1 o : 29.V.1963 (Fig. 2), 1 o: 1.VI.1963; slide No. TB1810f (Figs. 3, 7), 2 o : 3.VI.1963 (Figs. 4, 5). All specimens are deposited in HNHM.
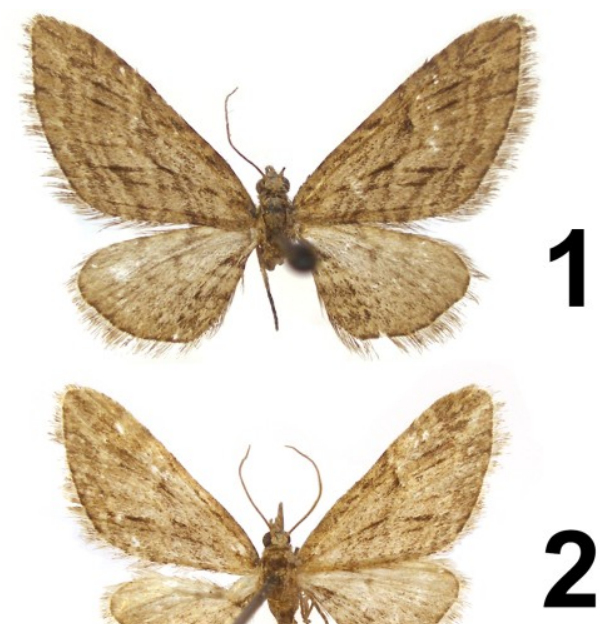

2
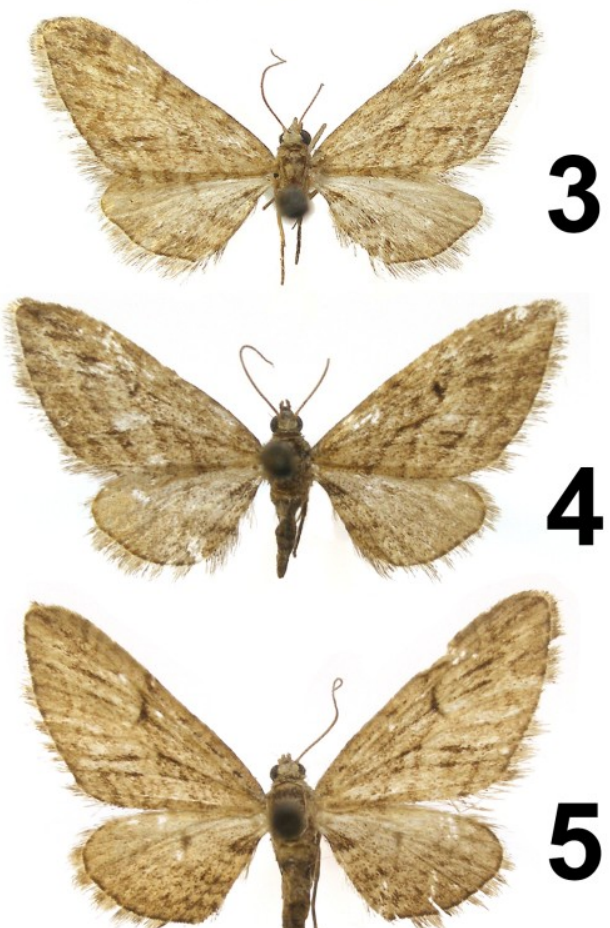

Sátor hegys, Hung. Nat. Hist. Mus. Coll. Lepidoptera Telk; baing a 2004-6 1965.0 .28 coll. Rácz Gábor_ TB1809 abiveviata leg. Rácz Gábor
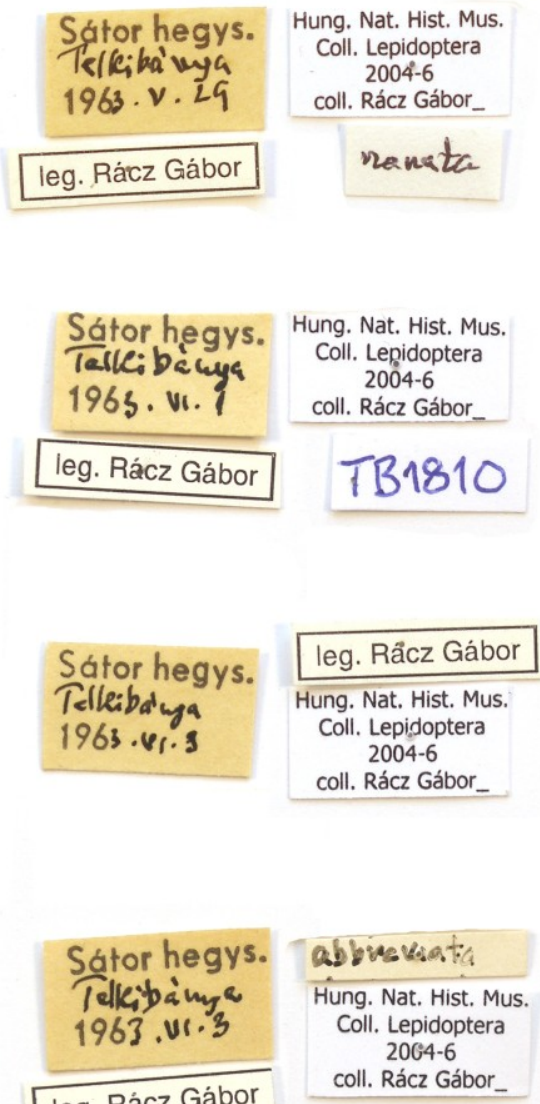

leg. Rácz Gábor coll. Rácz Gábor_

Figures 1-5. Adults in dorsal view, and corresponding labels of Eupithecia oxycedrata collected in Hungary. Scale bar: $10 \mathrm{~mm}$. 


\section{RESULTS}

External morphology of the specimens (Figs. $1-5)$ is characterised by the elongated forewing, the relatively uniform ground colour, the more-orless parallel transverse lines and the black longitudinal streaks near vein $\mathrm{Cu} 2$ as well as on veins M1 and M2. In the female genitalia (Figs. 6, 7) the most characteristic trait is the presence of large and strong spines on the left side of ductus bursae. Specimen TB1809f has only two spines, while the other dissected specimen (TB1810f) has the complete row of spines.

There are three closely related, similar species known to occur in Central Europe: Eupithecia oxycedrata, Eupithecia pusillata ([Denis \& Schiffermüller], 1775) and Eupithecia ericeata (Rambur, 1833). This group is characterised by the more-or-less elongated shape of forewing, the acutely angled antemedial line with a long and straight section below cell and the straight medial line, which is less slanted than the antemedial.
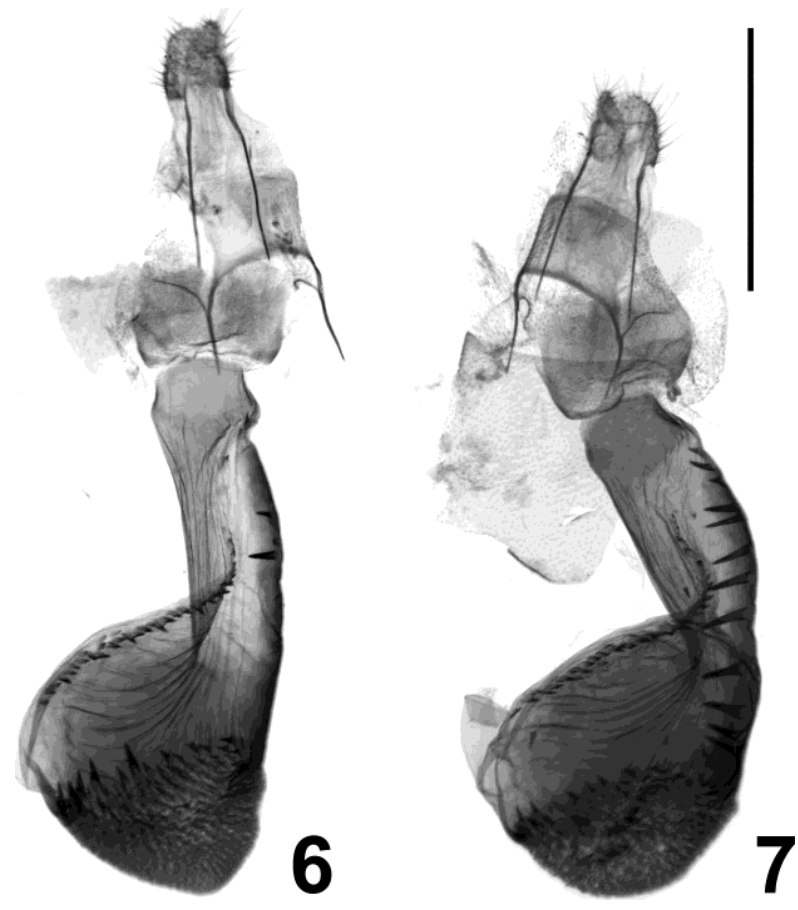

Figures 6-7. Female genitalia of Eupithecia oxycedrata in ventral view, collected in Hungary. Fig. $6=$ Sátor-hg., Telkibánya, 1963.V.28, leg. Rácz Gábor; slide No. TB1809f (coll. HNHM), fig. 7 = Sátor-hg., Telkibánya, 1963.VI.1, leg. Rácz Gábor; slide No. TB1810f (coll. HNHM). Scale bar: $1 \mathrm{~mm}$.
Difference between $E u$. oxycedrata and Eu. pusillata is the shape of postmedial line: it meets the dorsum at obtuse angle in Eu. oxycedrata while at nearly right angle in Eu. pusillata. In addition, Eu. pusillata lacks the conspicuous black streaks at vein $\mathrm{Cu} 2$ which are present in $E u$. oxycedrata.

Compared to Eu. ericeata, the ground colour of Eu. oxycedrata is more uniform than that of $E u$. ericeata. The apical area of Eu. oxycedrata is usually uniform, and the colour of the area bordered by the medial line, vein M3, postmedial line and vein $\mathrm{Cu} 2$, is like the ground colour of the forewing. On the contrary, the apical area of $E u$. ericeata is usually divided to a dark dorsal and a light ventral part, and the above-mentioned medial field is usually lighter than the ground colour, especially in males. The transverse lines of Eu. oxycedrata appear to be more parallel with each other than in Eu. ericeata because the medial line is usually less prominent in the former species than in the latter taxon.

Eupithecia oxycedrata can be distinguished from the two other species by its more elongated forewing shape. Nevertheless, specimens difficult to identify do exist, in these cases only genital dissection can provide positive identification.

In the male genitalia the apex of sternum A8 of $E u$. oxycedrata is less deeply bifurcated than that of either Eu. pusillata or Eu. ericeata, and the valval sacculus in Eu. oxycedrata does not have any extension while in both other species there is a spine-like saccular terminal process. In the female genitalia of Eu. oxycedrata the best character is the presence of large and strong spines on the left side of ductus bursae in ventral aspect which are either completely absent (Eu. ericeata) or reduced in length (Eu. ericeata, Eu.pusillata) in the closely related species.

\section{DISCUSSION}

Identity. I identify the specimens as Eu. oxycedrata because all features are unanimously characteristic to this species. This is the first record of 
this taxon from Hungary, thus the number of Eupithecia species collected in Hungary raises to 69.

Collecting site. Gábor Rácz collected these specimens at light in a Pinus sylvestris L. plantation near the tourists' hostel of Telkibánya, $c a$. 290 m a.s.l, in Zemplén Mountains. This building was later demolished and replaced by a larger construction (Gábor Rácz, pers. comm.), currently known as "Ezüstfenyő Hotel". The occurrence of Eu. oxycedrata in Zemplén Mountains is highly unexpected because this area is completely different from all habitats known for this species in the Mediterranean region. In addition, the primary host plant Juniperus oxycedrus is not known to occur in Hungary. On the other hand, the fact that a small series of specimens was caught within a week, together with other Eupithecia individuals representing different species, reduces the possibility of mislabelling.

Although the use of $J$. oxycedrus as ornamental shrub is not typical in Hungary (Zoltán Barina, pers. comm.), I think the most plausible explanation of the occurrence of Eu. oxycedrata is still the introduction of its premature stages with host plant. This theory is perhaps supported by the fact that before World War II the aforementioned building was used as a hunting mansion, maybe with exotic plants in its garden.

Data from Central Europe. In the Carpathian Basin only one record of Eu. oxycedrata was so far known: László Diószeghy collected one specimen in Retezat Mountains, near Lenşițu, at 1200 $m$ a.s.l (Diószeghy 1929-1930). Unfortunately the voucher specimen cannot be found in the Diószeghy Collection at the Museum of Covasna county, Romania (Căpuşe \& Kovács 1987) and I was not able to locate it in the collection of HNHM despite the presence of several Eupithecia specimens collected by Diószeghy in the Retezat Mountains or in other localities. Mironov (2003) illustrated this record in the distributional map of this species, notwithstanding the lack of the voucher. Maybe it is worth to note that this old record from Retezat Mountains seems to be at least as mysterious as the new data from Telkibánya.

The record from Zemplén Mountains is by far the most northern occurrence of the species and the only one known in the Pannonian region of the Carpathian Basin (Fig. 8).

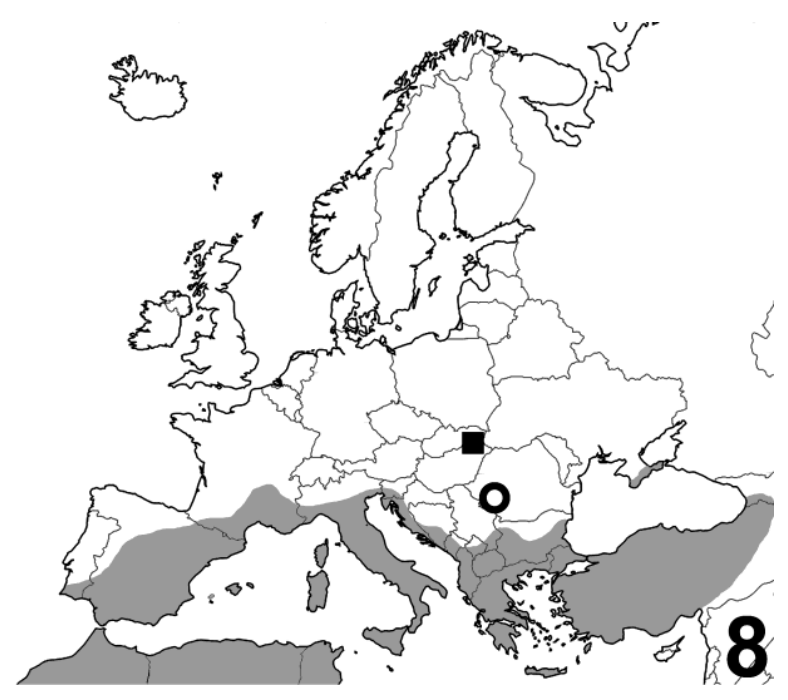

Figure 8. Distribution of Eupithecia oxycedrata in Europe. Light grey area: continuous range after Mironov (2003); black square: Zemplén Mountains, Telkibánya, 1963.V.28VI.3., leg. Gábor Rácz; open dot: Retezat Mountains, Lenşiţu, 26.V.[year unknown, before 1930], leg. László Diószeghy.

Acknowledgements - I am indebted to Zsolt Bálint, Gergely Katona and László Ronkay (HNHM) for their very useful advices during the preparation of the manuscript. I express my sincere thanks to Levente Székely (Săcele, Braşov, Romania) for provision and suggestion of old literature. I am grateful to Gábor Rácz for much valuable information on the collecting site as well as its history, and to Zoltán Barina (HNHM) for information on Juniperus oxycedrus.

\section{REFERENCES}

CĂPUȘE, I. \& KovÁCS, S. (1987): Catalogul colectiei de lepidoptere "László Diószeghy" de la Muzeul judetean Covasna, Sfintu Gheorghe / Catalogue de la collection de Lépidoptères "László Diószeghy" du Musée departemental Covasna, Sfintu Gheorghe [Catalogue of the Lepidoptera collection of László Diószeghy at the Museum of Covasna county, Sfântu Georghe]. Institutul de speologie "Emil Racovița", Bucharest, 397 pp. 
DiÓSZEGHY, L. (1929-1930): Die Lepidopteren-Fauna des Retyezat-Gebirges [The Lepidoptera fauna of the Retyezát Mountains]. Verhandlungen und Mitteilungen des Siebenbürgischen Vereins für Naturwissenschaften zu Hermannstadt, 79-80(1): 188-289.

FARJON, A. (2013): Juniperus oxycedrus. The IUCN Red List of Threatened Species 2013: e.T42243 A2965838. doi: 10.2305/IUCN.UK.2013-1.RLTS.T 42243A2965838.en Downloaded on 23 April 2018.

DE LAEVER, E. (1960): Etudes sur le genre Eupithecia
Curtis [Studies on the genus Eupithecia Curtis]. Bonn Zoological Bulletin, 11(1): 114-123.

Mironov, V. (2003): Larentiinae II (Perizomini and Eupitheciini). In. HAUSMANN, A. (Ed.) The Geometrid Moths of Europe 4. Apollo Books, Stenstrup, $463 \mathrm{pp}$.

PASTORÁlis, G., BUSCHMANN, F. \& RONKAY, L. (2016): Magyarország lepkéinek névjegyzéke / Checklist of the Hungarian Lepidoptera. e-Acta Naturalia Pannonica, 12: 1-258. 